\title{
STRATEGI PENGUATAN HALAL SUPPLY CHAIN DI INDONESIA DALAM MENGHADAPI GLOBAL ISLAMIC ECONOMY
}

\author{
Aslikhah, Alimatul Farida \\ Universitas Yudharta Pasuruan \\ aslikhah@yudharta.ac.id
}

\begin{abstract}
Abstrak
Masyarakat muslim ataupun non muslim di beberapa negara di dunia, telah mengambil peluang besar industri halal. Negara- negara yang penduduknya mayoritas beragama Islam saling berkompetisi untuk menjadi halal supply chain dunia. Tujuan Penulisan artikel ini adalah untuk mengetahui 1) strategi KNKS dalam penguatan rantai pasok halal (halal supply chain) pada produk halal di Indonesia 2)Strategi dari Kementrian Perencanaan Pembangunan Nasional dalam percepatan halal supply chain Industri halal di Indonesia 3) Untuk mengetahui kondisi ekonomi syari'ah Indonesia dalam global Islamic Economy. Artikel ini menggunakan data sekunder yang didapatkan melalui laporan pada GIE 2020/2021 Report, KNKS, dan Kementrian Perencanaan Pembangunan Nasional . Analisis data pada artikel ini dengan menggunakan empat tahap yaitu reduksi data, kategorisasi data selanjutnya dilakukan verifikasi data, dan yang terakhir dengan display data. Penarikan kesimpulan dilakukan dengan cara mendeskripsikan laporan pada table- table . Dapat disimpulkan bahwa, Indonesia dengan jumlah penduduk yang besar dan mayoritas muslim merupakan negara tujuan untuk investasi akan produk halal, strategi- strategi yang dilakukan oleh para pemangku kepentingan diarahkan pada penguatan halal supply chain Indonesia menuju poros halal dunia.
\end{abstract}

Keywords: Strategy: Halal Supply Chain; Global Islamic Economy

\begin{abstract}
Muslim and non-Muslim communities in several countries in the world have taken great opportunities in the halal industry. Countries with a majority Muslim population compete with each other to become the world's halal supply chain. The purpose of writing this article is to find out 1) the KNKS strategy on strengthening the halal supply chain for halal products in Indonesia 2) The strategy of the Ministry of National Development Planning in accelerating the halal supply chain of the halal industry in Indonesia 3) To determine economic conditions of Indonesia in the global Islamic Economy. This article uses secondary data obtained through reports on the GIE 2020/2021 Report, KNKS, and the Ministry of National Development Planning. Data analysis in this article uses four stages, namely data reduction, data categorization, then data verification, and finally with data display. Conclusions are drawn by describing the report in the tables. It can be concluded that, with a large population and a Muslim majority as a destination country for investment in halal products, the strategies undertaken by stakeholders are directed at strengthening Indonesia's halal supply chain towards the world's halal axis.
\end{abstract}

Keywords: Strategy: Halal Supply Chain; Global Islamic Economy 


\section{A. PENDAhULUAN}

Berikut ini adalah data urutan agama terbesar dunia yang dirilis oleh pew research center Berdasarkan data Pew Research Center, agama terbesar di dunia 2020 adalah Kristen yang merupakan gabungan dari umat Protestan dan Katolik. Adapun, jumlah pemeluk agama Kristen di seluruh dunia mencapai 2,3 miliar. Kemudian, urutan agama terbesar di dunia diduduki oleh Islam dengan jumlah pengikut mencapai 1,9 miliar.Selanjutnya diikuti oleh kelompok yang tidak berafiliasi pada agama sebanyak 1,1 miliar. Ada juga agama Hindu, Buddha, agama rakyat, agama lain, dan Yahudi yang masuk ke dalam suvei agama terbesar di dunia.

Tabel 1: Populasi agama di dunia tahun 2020

\begin{tabular}{|l|l|c|}
\hline No & \multicolumn{1}{|c|}{ Agama } & Jumlah Pengikut \\
\hline 1 & Kristen & 2.382 .750 .000 \\
\hline 2 & Islam & 1.907 .110 .000 \\
\hline 3 & Tidak Berafiliasi pada Agama & 1.193 .750 .000 \\
\hline 4 & Hindu & 1.161 .440 .000 \\
\hline 5 & Budha & 506.990 .000 \\
\hline 6 & Agama Rakyat & 429.640 .000 \\
\hline 7 & Agama lain & 60.990 .000 \\
\hline 8 & Yahudi & 14.660 .000 \\
\hline
\end{tabular}

Dari data yang dirilis Pew Research Center diatas menunjukkan bahwa populasi agama Islam menempati posisi kedua terbesar dunia setelah agama Kristen. Hal ini tentunya menjadi peluang besar sekaligus tantangan yang tidak ringan bagi para pemangku kepentingan dalam upaya pemenuhan kebutuhan konsumsi halal masyarakat Muslim baik di Indonesia maupun dunia.

Data dari World Population Review pada tahun 2020 penduduk yang beragama Islam di Nusantara hingga mencapai angka 229 juta jiwa atau atau 87,2 persen dari total keseluruhan jumlah penduduk di negara Indonesia yang mencapai angka 273,5 juta jiwa. Populasi penduduk Muslim nusantara tersebut dapat menyumbangkan Produk Domestik Bruto (PDB) hingga mencapai angka US\$ 3,8 miliar per tahun dalam roadmap Industri halal nasional. Dari data ini tentu saja jumlah populasi penduduk Indonesia yang beragama Islam dan kontribusi terhadap Industri halal nasional bukanlah angka yang kecil, dan diyakini akan terus meningkat Indonesia sebagai mesin ekonomi halal global (Engine of global halal economy). Dari data- data yang dapat diketahui diatas, menunjukkan bahwa populasi Muslim baik di dunia maupun di Indonesia yang tinggi tersebut bisa menjadi peluang dan tantangan untuk industri halal di Indonesia dan Dunia.

Kualitas produk yang sesuai dengan prinsip dalam Islam dan digunakan sebagai aktivitas yang dikerjakan oleh umat Muslim merupakan konsep halal . Jasa 
dan produk halal dipilih oleh masyarakat Islam merupakan wujud kepatuhan pada hukum syariah. Negara Rusia yang berada pada urutan kesembilan dalam hal konsumsi produk halal. Selain itu konsumen non muslim juga membutuhkan produk halal dengan alasan etis. hal ini dikarenakan didalam produk- produk halal ada jaminan- jaminan yang dikehendaki oleh masyarakat, baik Muslim ataupun non Muslim, jaminan- jaminan tersebut meliputi kebersihan, jaminan produk yang aman untuk dikonsumsi, dan jaminan kualitas produk untuk seluruh rantai produksi dari hulu sampai hilir (from farm to plate).

\section{B. KAJIAN TEORI}

Konsep halal adalah istilah yang bersumber dari al Qur'an yang memiliki arti boleh, diijinkan atau sah. Dalam konteks halal ini salah satu stakeholder pemegang otoritas terkait kehalalan suatu produk di Indonesia yaitu MUI ( Majelis Ulama Indonesia) menyatakan bahwa bagi umat Islam, perintah untuk mengkonsumsi yang halal, suci, dan baik merupakan perintah agama dan hukumnya wajib. Cukup banyak dalil- dalil yang menjelaskan terkait hal ini diantaranya adalah didalam surat al Baqarah ayat 168 dijelaskan:

"Hai sekalian manusia! Makanlah yang halal lagi baik dari apa yang terdapat dibumi, dan janganlah kamu mengikuti langkah- langkah setan, karena sesungguhnya setan itu adalah musuh yang nyata bagimu” (al Baqarah: 168). Dijelaskan juga didalam al Qur'an Surat al Maidah ayat 88 yaitu:

"Dan makanlah makanan yang halal lagi baik dari yang Allah telah rezekikan kepadamu dan bertakwalah kepada Allah yang kamu beriman kepadaNya."(al Maidah:88).

Moral Sistem/ moral driven dapat digunakan dalam aktivitas untuk menghasilkan halal produk baik berupa barang atau jasa dalam Islam (Haider Naqvi, 1981). Hal ini menandakan bahwa moral dapat menjadi panduan untuk dapat menghasilkan produk berupa barang atau jasa dan dapat mengefisiensikan kinerja dan produktifitas, meningkatkan profit atau laba, serta menumbuhkannya secara luas dan menyeluruh. Tingkat kepentingan moral value dalam menghasilkan barang atau jasa memiliki makna pengagungan manusia sebagai makhluk Allah SAW, aktualisasi kemampuannya sebagai pemimpin di bumi, serta menjalankan peran dan fungsi sosial bagi masyarakat. Pendapat ini menolak argument bahwa keberadaan manusia hanya sebagai makhluk ekonomi saja . Di dalam pandangan homo economicus, bahwa moral itu terpisah dengan ekonomi. Dan sebaliknya didalam ajaran Islam, perilaku produksi adalah sebuah menifestasi ibadah manusia kepada sang Khalik, moralitas dan kepatuhan manusia pada sang Tuhannya. Menghilangkan keberadaan moral dapat menimbulkan aliensi ekonomi dari kehidupan manusia di bumi ini. Dalam melakukan aktivitas produksi, hendaknya menerapkan moral value yang bersumber dari ajaran wahyu Allah SWT dan as Sunnah Rasulullah SAW, dalam kaitannya untuk memenuhi 
permintaan konsumen, proses produksi untuk mendapatkan modal, pertumbuhan usaha serta diversifikasi produk dalam keberlangsungan usaha tersebut. Hal ini dikarenakan antara nilai moral dan kegiatan berproduksi dapat berpengaruh secara langsung terhadap kehidupan sosial.

Ikatan teologis memiliki hubungan yang kuat dalam beraktivitas bisnis. Manusia dalam melakukan bisnis tidak boleh lepas sedikitpun dari ikatan teologis sebagaimana yang diajarkan dalam Islam. Dengan ikatan teologis pelaku bisnis harus tunduk dan patuh pada ketentuan, agar manusia yang beriman selalu menghargai martabat kemanusiaan (humanity) secara universal dan mengedepankan nilai- nilai etis di dalam masyarakat.

Perenungan filosofis dimaksudkan mengadakan refleksi untuk memahami sesuatu yang paling dasar,unsur- unsur atau syarat- syaratnya yang paling hakiki, untuk dapat memahami semua fakta atau segi yang ada.Dengan melalui perenungan filosofis ini kita akan memahami bahwa inti aktivitas ekonomi adalah perilaku. Perilaku para pelaku ekonomi, bisa rumah tangga- rumah tangga, bisa perusahaanperusahaan, dan bisa pemerintahan. Beberapa faktor produksi dalam ekonomi dapat dinyatakan dalam (Sri Laksmi, 2015): Sumber daya manusia atau tenaga kerja, sumber daya alam sebagai bahan baku atau bahan penolong lainnya dan modal serta faktor produksi skill atau manajemen.

\section{METODE PENELITIAN}

Artikel ini merupakan artikel dengan pendekatan deskriptif kualitatif. Adapun data yang terhimpun untuk kebutuhan riset ini adalah dengan menggunakan data- data sekunder yang bersumber pada data- data yang didapatkan dari laporan resmi Global Islamic Economy 2020/2021 Report. Data enam strategi dari KNKS dalam www.knks.go.id. Data dari Kementrian Perencanaan Pembangunan Nasional, Masterplan Ekonomi Syari'ah 2019- 2024. Ada empat tahap yang digunakan dalam menganalisis artikel ini yaitu dimulai dari reduksi data, kemudian dilakukan kategorisasi data, setelah itu diadakan verifikasi data dan yang terakhir display data. Reduksi data dengan cara melakukan pemotongan dan penyederhanaan data, dan dalam penelitian ini dilakukan dengan menyeleksi semua data yang sudah terkumpul melalui pemotongan dan penyederhanaan data yang ada. Setelah reduksi data, kemudian dilakukan kategorisasi data yang disesuaikan dengan topik penelitian yaitu "Strategi Penguatan Halal Supply Chain di Indonesia Dalam Menghadapi Global Islamic Economy". Tahap selanjutnya yaitu melakukan verifikasi data, verifikasi digunakan untuk mencocokkan data dengan topik dalam penelitian ini. Display data pada artikel ini yaitu dengan menyajikan data- data dalam bentuk simbol- simbol, diagram dan deskripsi- deskripsi untuk menjelaskan maksud dari data- data yang disajikan. Dan pada penarikan konklusi atau kesimpulan merupakan interpretasi peneliti terhadap data- data yang telah disajikan. 


\section{HASIL DAN PEMBAHASAN}

\section{Strategi KNEKS Dalam Pengembangan Halal Value Chain menghadapai Global Islamic Economy}

Komite Nasional Keuangan Syari'ah ( KNKS) sedang membentuk suatu strategi nasional pengembangan industri halal Indonesia. Salah satu langkahnya dengan menerapkan manajemen halal supply chain dengan baik. Dalam manajemen halal supply chain, memperhatikan berbagai hal terkait produk dan jasa dari sebelum sampai di tangan konsumen hingga di tangan konsumen. Diantaranya memperhatikan dari mana asal bahan bakunya, siapa yang mmproses, dibawa kemana, di simpan oleh siapa, transportasinya menggunakan apa, kemasannya seperti apa sampai dikirim ke konsumen seperti apa.

a. Strategi KNEKS untuk meningkatkan Halal Supply Chain Menuju Indonesia Pusat Halal Dunia .

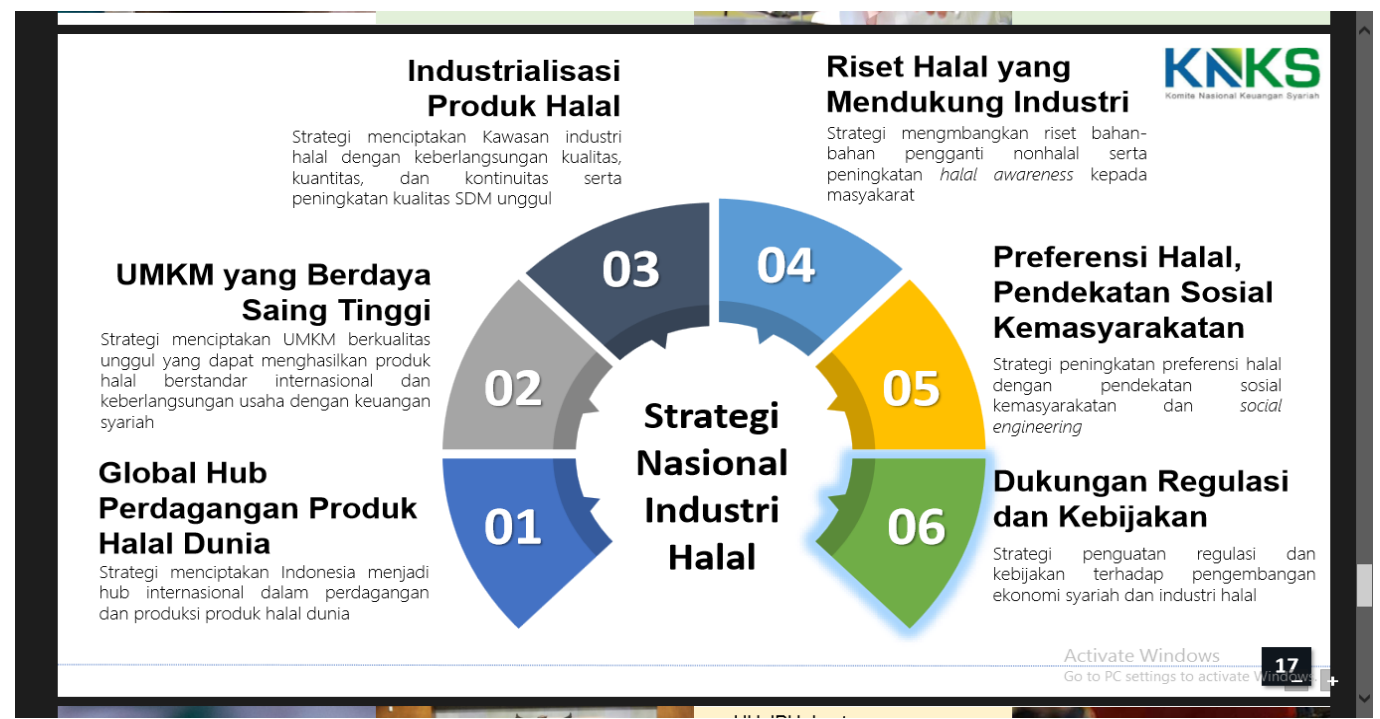

Sumber: Data KNKS

Gambar 1. Strategi Halal Supply Chain

1) Strategi pertama yang dilakukan KNKS dalam Strategi Nasional Industri Halal yaitu bagaimana Indonesia sebagai poros halal dunia dengan beberapa strategi berikut ini:

a) Kolaborasi dengan pelaku industri dunia sebagai halal supply chain sistem

- Perusahaan- perusahaan seperti sebagai (World Center of Excellence for Muslim Products)

- Investasi asing secara langsung

- Integrasi Kawasan Industri Halal

- Sistem Transportasi halal

- Halal Warehouse System 
- Halal Port

b) Indonesia's halal certificate, world recognition

- Majelis Ulama Indonesia (MUI) dan BPJPH

- Menjadi Peminpin Standar Halal secara Global

- Perluasan Halal secara Internasional

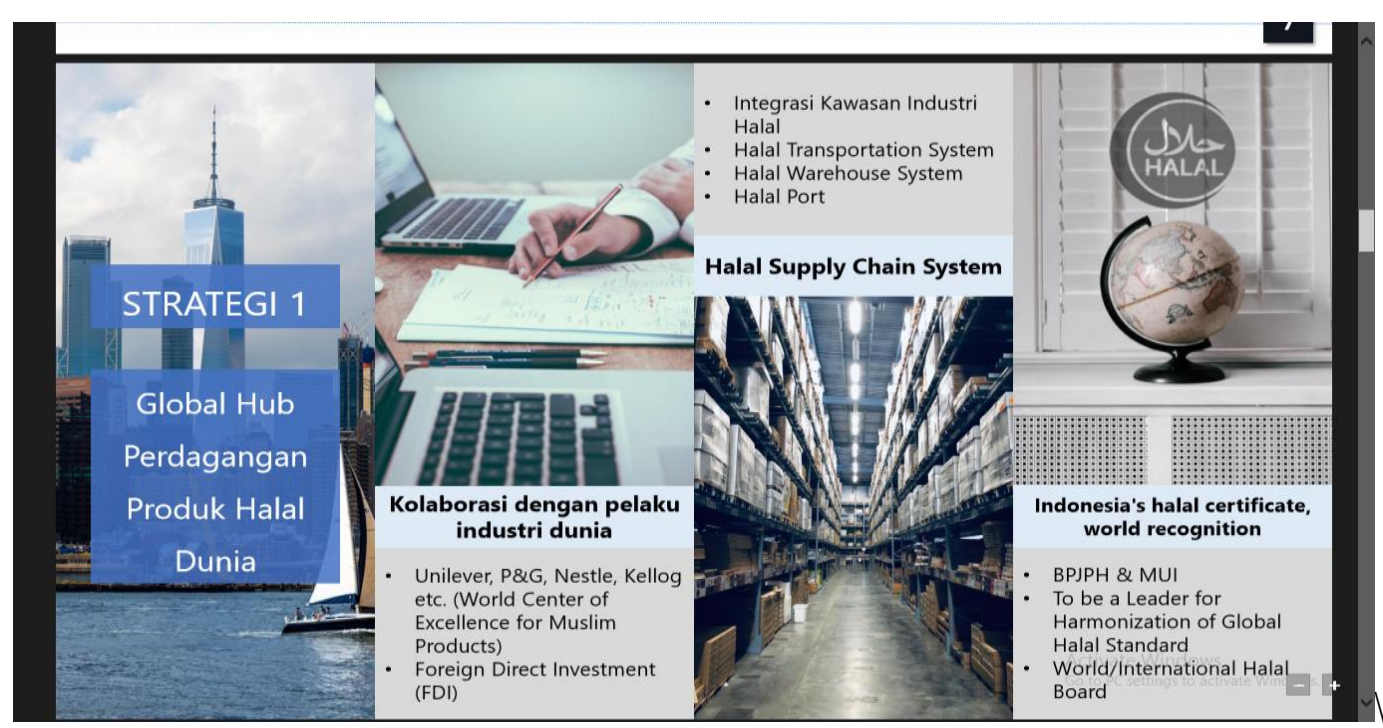

Gambar 2. Strategi 1 KNKS

2) Strategi kedua yang dilakukan KNKS dalam Strategi Nasional Industri Halal yaitu dengan Mengupayakan Usaha Mikro Kecil dan Menengah (UMKM) dapat mencapai kualitas unggul yang dapat memproduksi produk halal yang berstandar internasional untuk kelangsunagn usaha dengan Islamic finance. Strategi- strategi yang dilakukan dapat dilihat pada Gambar 3 sebagai berikut:

a) Pembiayaan syari'ah dan ekonomi digital

b) Melakukan Pembinaan

3) Strategi Nasional Industri Halal KNKS yang ketiga yaitu dengan membentuk sebuah kawasan halal industry dengan cara keberlangsungan dalam hal kualitas, kuantitas, dan kontinuitas serta peningkatan kualitas sumber daya manusia dengan beberapa strategi berikut ini:

a) Dibentuknya Kawasan Industri Halal di Indonesia

- Produk Berkualitas

- Kuantitas dan Kapasitas

- Keberlanjutan Produksi

b) Peningkatan Kompetensi SDM Pekerja Industri

- Pendidikan Vokasi Industri

- Training dan Peningkatan Keterampilan 


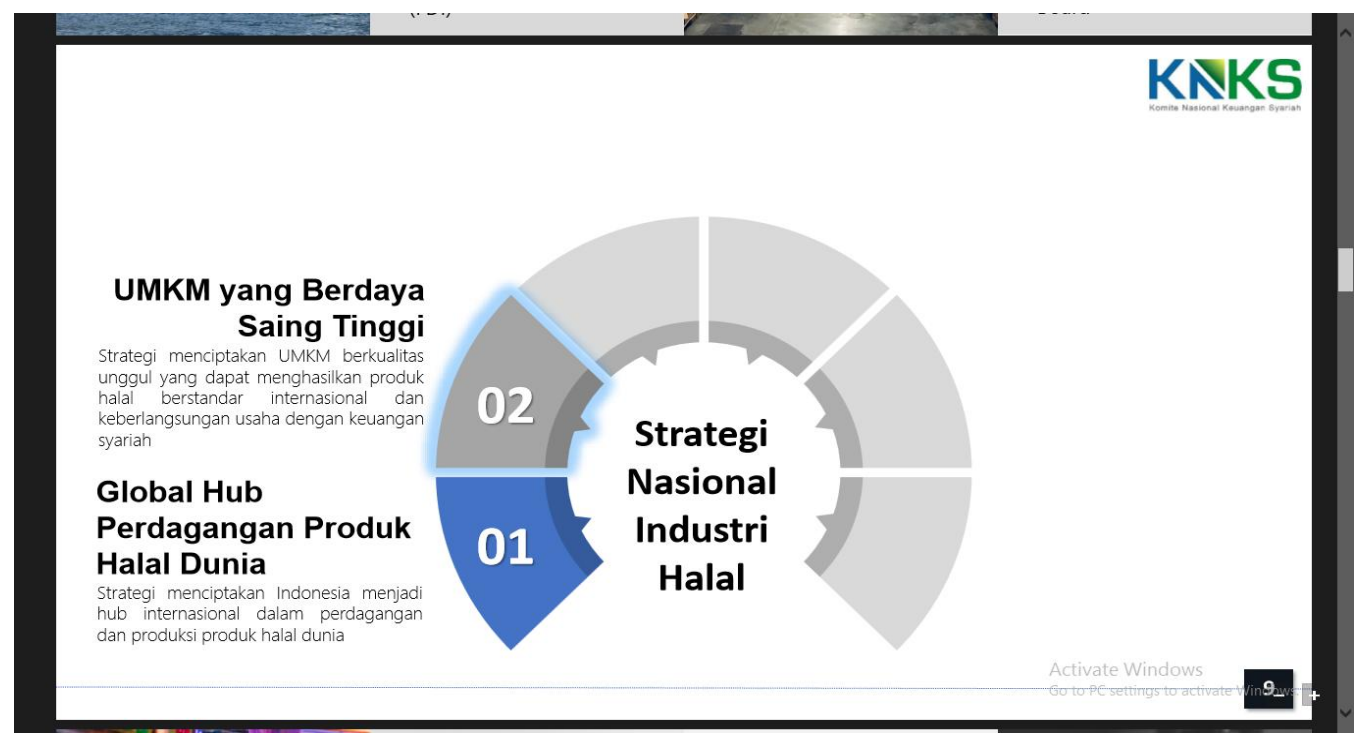

Gambar 3. Strategi 2 KNKS

c) KlasterisasiProduk Halal

- Lokal/Kabupaten

- Regional/Kepulauan

- Produk dan Sektoral

4) Strategi Nasional Industri Halal KNKS yang keempat yaitu strategi penelitian halal yang dapat mendukung industri, dengan cara mengembangkan penelitian pada bahan- bahan pengganti yang non halal serta peningkatan kepedulian halal pada masyarakat secara luas dengan beberapa strategi berikut ini:

a) Penelitian dan Pengembangan - Penggantian non halal

- Penelitian pada bahan dasar dalam negeri

- Kebijakan terkait bahan industri

b) Program Kepedulian Halal

- Membangun kepedulian halal bagi pelaku industri

- Training, academic dan nonacademic

c) Pelayanan Laboratorium

- Tes halal, Penelitian akademik dan percontohan industri

5) Strategi Nasional Industri Halal KNKS yang kelima yaitu preferensi halal, pendekatan sosial kemasyarakatan dengan strategi peningkatan preferensi halal dengan pendekatan sosial kemasyarakatan dan social engineering, dengan beberapa strategi sebagai berikut:

a) Terminologi dan pemahaman yang Sama antara halal, syari'ah atau Islami, penjaminan sistem asuransi dan halal inklusif

b) Program Halal Lifestyle Social Development

- Social Re-engineering • Halal lifestyle campaigns

c) Melakukan Level Level of Compliances 
- Pendekatan Politik lokal

- Kearifan local

6) Strategi Nasional Industri Halal KNKS yang keenam yaitu dukungan terhadap peraturan dan kebijakan terhadap penguatan regulasi dan kebijakan untuk pengembangan ekonomi syariah dan industri halal dengan beberapa strategi yaitu:

a) Intervensi Pemerintah

- Menetapkan standar biaya sertifikasi halal pada Industri menengah dan besar, pada Usaha Mikro Kecil Dan Menengah (UMKM).

- Penguatan pada lembaga- lembaga yang konsen pada pengembangan Industri halal

b) Undang- Undang Jaminan Produk Halal dan regulasi turunannya

- Undang- Undang Jaminan Produk Halal ( UUJPH) dan turunannya

- Regulasi dari Kemenag, Regulasi dari Menkeu, Regulasi dari Menperin (Menteri Perindustrian), peraturan dari Menpar (Menteri Pariwisata), dan Menteri Perdagangan terkait dengan Halal.

- Proses sertifikasi halal, murah, mudah dan cepat

c) Melakukan penguatan pada Fatwa Halal dan Halal Standard

- Penguatan Komisi Fatwa - Majelis Ulama Indonesia (MUI)

- Standar Nasional Indonesia (SNI) Badan Standarisasi Nasional

Dari enam strategi yang dilakukan oleh KNEKS tersebut, dapat diyakini industri halal yang ada Indonesia dapat menembus pasar Internasional, hal ini dapat dilihat dari kondisi dan posisi negara Indonesia dalam ekonomi Islam secara global, mengalami peningkatan dari tahun ke tahun.

\section{Masterplan Ekonomi Syari'ah Menuju Indonesia Sebagai Pusat Halal Dunia}

a. Strategi pada Klaster Makanan dan Minuman Halal

Dengan diterbitkannya Undang- Undang No. 33 Tahun 2014, tentang jaminan produk halal sebagai upaya untuk akselesari industri halal di Indoenesia. Akan tetapi pengembangan industri halal masih terkendala dengan terbatasnya suplai bahan baku yang memenuhi kriteria halal. Dengan adanya UU tersebut percepatan dan pertumbuhan industri halal pada klaster makanan dan minuman halal dapat segera terwjudkan.

b. Strategi pada Klaster Pariwisata Halal

1) Disusunnya serangkaian paket wisata halal terintegrasi pada masing- masing daerah yang memiliki keunggulan destinasi wisata

2) Eksibisi dan branding halal melalui media sosial

3) Pada era revolusi industri 4.0 saat ini, berbagai macam produk unggulan pariwisata halal harus bisa dikenalkan kepada masyarakat global. Dan saat 
ini media social merupakan cara efisien dalam rangka penguatan branding pariwisata halal.Oleh karena itu, diperlukan sebuah satuan kerja khusus di tingkat pusat maupun daerah untuk mempromosikan pariwisata halal melalui media sosial untuk mendapatkan tingkat awareness yang bersaing dengan destinasi wisata lainnya.

4) Straegi cepat oleh pemerintah daerah (Pemda) dapat dirumuskan dengan peraturan daerah tentang Pariwisata Halal dan disahkan bersama dengan wakil rakyat tingkat daerah, selanjutnya pemimpin daerah menjadi ujung tombak perumusan pelaksanaannya sehingga mempunyai daya saing dalam meningkatkan pariwisata daerah. Program ini merupakan bagian dari quick wins utama masterplan ekonomi syariah berupa penguatan aspek hukum dan koordinasi.

c. Strategi Pada Fashion Muslim

1) Dilaksanakannya business matching forum

2) Dilakukannya kampanye untuk lebih mencintai pada produk fesyen Muslim karya anak bangsa melalui berbagai media dan komunitas.

3) Dilakukannya event pengenalan produk fesyen untuk promosi bertaraf internasional pada fesyen Muslim.

d. Strategi pada rekreasi halal dan Media .

1) Sektor unggulan dan prioritas media dan rekreasi harus dibentuk.

2) Skema pembiayaan halal harus terus dimotivasi

e. Strategi pada klaster farmasi dan kosmetik halal

1) Membentuk berbagai kegiatan dan media untuk sosialisasi gerakan gaya hidup halal.

2) Kerjasama antara BPOM dan LPPOM harus dilakukan dengan solid karena terkait kebijakan halal pharma dan kosmetika halal.

3) Harus dilakukan pengelompokan bahan baku yang terindikasi tercampur atau mengandung unsur- unsur yang dilarang/ diharamkan atau tidak jelas status kehalalannya.

f. Strategi pada klaster energy terbarukan

1) Mengkampanyekan keunggulan energi terbarukan untuk mencapai kemandirian pada energy nasional.

2) Dimudahkannya akses dan skema pada financing yang menarik untuk mensupport terciptanya kemudahan pada energy terbarukan.

\section{Data Posisi Negara Indonesia dari GIE 2020/2021 Report}

Dalam beberapa tahun terakhir tren halal lifestyle sudah menjadi sebuah kebutuhan, hal ini dapat dilihat dari perkembangan pada halal industri diantaranya yaitu: halal food, Islamic finance, pakaian dan modest, kosmetik dan obat- obatan, media dan rekreasi muslim friendly travel. Data Laporan dari GIE 2020/ 2021 yang 
dirilis pada website www.salaamgateway.com, pada data tersebut posisi negara Indonesia berada dalam posisi 10 besar pada setiap indicator dalam global islamic report. Tentunya hal ini menunjukkan bahwa Indonesia mampu bersaing secara kompetitif dengan negara- negara lain di dunia dalam hal ekonomi Islam secara global, baik itu dari sisi permintaan maupun penawaran. Kondisi ini dijadikan panduan sekaligus motivasi oleh para pemangku kepentingan dan para pemberi regulasi dan kebijakan terkait pengembangan halal value chain pada industri- industri di Indonesia, baik industri manufacturing maupun industri jasa.

Tabel 2. Top 10 Indicator Score Rank By Sector

\begin{tabular}{|l|l|l|l|l|l|l|}
\hline & $\begin{array}{l}\text { Makanan } \\
\text { halal }\end{array}$ & $\begin{array}{l}\text { Keuangan } \\
\text { Islam }\end{array}$ & $\begin{array}{l}\text { Muslim } \\
\text { Friendly } \\
\text { Travel }\end{array}$ & $\begin{array}{l}\text { Modest } \\
\text { Fashion }\end{array}$ & $\begin{array}{l}\text { Obat dan } \\
\text { Kosmetik }\end{array}$ & $\begin{array}{l}\text { Media dan } \\
\text { Rekreasi }\end{array}$ \\
\hline 1 & Malaysia & Malaysia & Malaysia & UAE & Malaysia & UAE \\
\hline 2 & Singapore & $\begin{array}{l}\text { Saudi } \\
\text { Arabia }\end{array}$ & UAE & Turkey & UAE & Malaysia \\
\hline 3 & UAE & UAE & Turkey & Indonesia & Singapore & Singapore \\
\hline 4 & Indonesia & Jordan & Thailand & Malaysia & Iran & $\begin{array}{l}\text { United } \\
\text { Kingdom }\end{array}$ \\
\hline 5 & Turkey & Bahrain & Tunisia & Spain & Egypt & Indonesia \\
\hline 6 & Iran & Indonesia & Indonesia & Italy & Indonesia & Brunai \\
\hline 7 & $\begin{array}{l}\text { South } \\
\text { Afrika }\end{array}$ & Kuwait & Azerbaijan & Bangladesh & France & Bahrain \\
\hline 8 & Pakistan & Pakistan & Jordan & Canada & $\begin{array}{l}\text { South } \\
\text { Africa }\end{array}$ & Lebanon \\
\hline 9 & Brunei & Qatar & Singapore & France & Turkey & Kuwait \\
\hline 10 & Russia & Nigeria & Albania & Iran & Tunisia & Netherlands \\
\hline
\end{tabular}

Sumber: GIE 2020/2021 Report. data diolah

Data ini berisi Top 10 rank indicator- indicator halal dari negara- negara di dunia yang dirilis setiap tahun pada www.salaamgateway.com oleh Thomson Routers yang bekerjasama dengan Dinar Standar terkait Global Islamic Economy Report yang diikuti oleh negara- negara di dunia. Data- data tersebut terkait pemeringkatan oleh masing- masing negara terhadap indikator- indikator hub halal yang meliputi; halal food, finance, Muslim friendly travel, fesyen, kosmetik, dan obat- obatan, media dan rekreasi. Dari data ini, dapat dilihat bahwasannya Indonesia menempati urutan keempat dalam suplai chain makanan halal. Pada posisi indicator islamic finance posisi Indonesia berada pada urutan enam, sementara untuk pada indicator Muslim friendly travel, negara Indonesia berada pada urutan enam. Untuk indicator modesf and fashion negara Indonesia berada pada urutan ketiga, pada indicator obat dan kosmetik posisi negara Indonesia berada pada urutan enam dan pada indicator media dan rekreasi posisi negara Indonesia berada pada kelima. 
Pada data investments overview 2019/ 2020 yang dirilis oleh GIE 2020/ 2021 report dibawah ini, menunjukkan bahwa sektor halal food menempati urutan pertama dibandingkan dengan indikator- indikator halal yang lainnya (Islamic Finance, Media, Travel \&Tourism, Halal Pharma, Modest Fashion dan Halal Cosmetics). Pada sektor halal food menempati urutan teratas dengan dengan nilai yang sangat tinggi dibandingkan dengan sektor- sektor yang lain.

Tabel 3. Investment Overview in 2019/2020

\begin{tabular}{|l|c|c|}
\hline & Total/ Deals & Value \$000s \\
\hline SECTOR & & $6,110,020$ \\
\hline Makanan halal & 61 & $4,925,120$ \\
\hline Islamic Finance & 38 & 121,050 \\
\hline Media & 27 & 340,103 \\
\hline Travel \& Tourism & 14 & 156,980 \\
\hline Halal Pharma & 9 & 3,450 \\
\hline Modest Fasion & 4 & 124,700 \\
\hline Halal Cosmetics & 3 & $9,031,089$ \\
\hline DEAL TYPE & 86 & 455,840 \\
\hline M\&A & 10 & $2,294,495$ \\
\hline PE & 60 & $\mathbf{1 1 , 7 8 1 , 4 2 4}$ \\
\hline VC & $\mathbf{1 5 6}$ & \\
\hline TOTAL & & \\
\hline
\end{tabular}

Sumber: GIE 2020/2021 Report data diolahsudah san

Kondisi ini menunjukkan bahwa halal food sudah menjadi kebutuhan primer bagi masyarakat muslim baik di bumi nusantara maupun negara- negara lain di dunia, hal ini menunjukkan bahwa halal food memiliki nilai investasi yang sangat besar baik di Indonesia maupun negara- negara lain didunia karena masyarakat Muslim menyadari urgensi dari konsumsi makanan halal ini, karena selain alas an religiusitas juga karena alasan etis. Sehingga . alas an etis inilah produk makanan dan minuman halal banyak dikonsumsi oleh penduduk dunia tidak hanya masyarakat Muslim tetapi juga masyarakat non Muslim dengan alasan kesehatan, dan keamanan. Dengan adanya data tersebut, dapat dijadikan panduan untuk negara Indonesia dalam strategi untuk meningkatkan halal value chain pada industri halal food mulai dari hulu sampai hilir, mulai dari penyediaan logistic sampai siap untuk dikonsumsi di tangan konsumen.

Selain data yang sudah disebutkan diatas, GIE 2020/ 2021 report juga merilis data terkait negara- negara di dunia sebagai pengguna atau konsumen pada produkproduk halal secara global. Tidak hanya negara- negara Muslim yang terganbung dalam Organisasi Kerjasama Islam (OKI) saja, tetapi negara- negara dengan penduduk minoritas Muslim juga mengambil bagian dalam hal supply and demand produk halal dunia. Berikut data Top 20 countries by number of $M \& A$. VC and PE deals in 2019/ 2020, yang dirilis oleh GIE 2020/2021 report: 


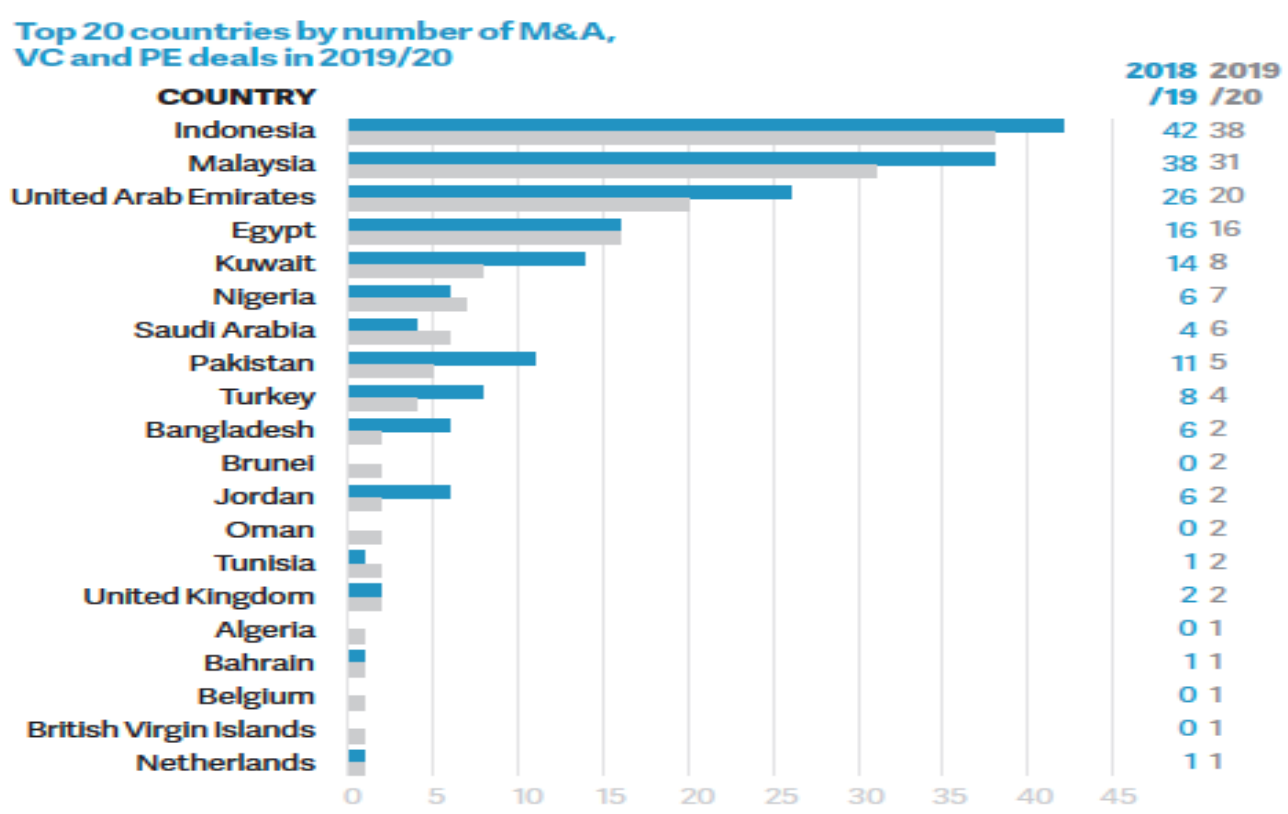

Sumber: GIE 2020/2021 Report

Gambar 2. Top 20 countries by number of M\&A. VC and PE deals in 2019/ 2020,

Data ini menunjukkan 20 negara teratas dengan angka modal dan asset global, ekuitas swasta, dan investasi modal ventura dalam konsumen, yang dirilis oleh State the Global Islamic Economy 2020/ 2021 Report, dari data ini menunjukkan bahwa posisi negara Indonesia berada pada posisi pertama dalam penyerapan produk halal dunia, dan secara berurutan dari tahun 2018/ 2019 dan tahun 2019/ 2020. Dengan paparan data yang telah disampaikan diatas, terkait negara- negara yang menyerap produk halal dunia, bahwa negara Indonesia merupakan negara yang memiliki potensi sangat besar untuk menyerap produk- produk halal dunia khususnya pada produk makanan dan minuman halal. Kondisi ini bisa menjadi acuan bagi para pemangku kepentingan untuk mengupayakan langkah, strategi dan kebijakan untuk mewujudkan Indonesia sebagai pusat halal supply chain dunia dengan terus meningkatkan dan mengimplementasikan halal value chain pada industri halal di Indonesia.

\section{E. KESIMPULAN}

Dari pemaparan pembahasan diatas dapat disimpulkan bahwa :

1. Dari laporan GIE 2020/2021 menunjukkan bahwa posisi Indonesia dalam data top 10 indicator score rank by sector halal food, Indonesia berada di posisi 4 , sedangkan data investment overview 2019/ 2020 investasi pada halal food untuk negaranegara di dunia, bahwa investasi halal food menempati posisi pertma dibandingkan investasi pada indikator- indikator halal yang lainnya. Dan data top 20 countries by number of M\&A, VC dan PE negara Indonesia berada di posisi teratas untuk tahun 2018/ 2019 dan tahun 2019/2020 dalam hal penyerapan produk-produk halal . Dan 
dari data KNKS ada enam strategi yang dilakukan oleh KNKS untuk mengupayakan strategi- strategi nasional untuk menjadikan Indonesia sebagai poros halal dunia.

2. Ada beberapa langkah cepat yang akan dilakukan oleh Kementrian Perencanaan Pembangunan Nasional sejak tahun 2018 dalam rumusan Masterplan Ekonomi Syariah Indonesia 2019- 2024. Strategi yang dilakukan pada setiap klaster produk halal yang meliputi makanan dan minuman halal, strategi dari klaster pariwisata halal, strategi pada klaster fesyen muslim, strategi pada klaster rekreasi halal dan media, strategi klaster pada farmasi dan kosmetik halal, dan strategi pada energi terbarukan

3. Seiring dengan perkembangan waktu dan globalisasi ekonomi, pada saat ini kebutuhan akan produk- produk halal sudah menjadi tren pada halal lifestyle masyarakat muslim Indonesia. Tren halal lifestyle menajadi kebutuhan mendasar dan mengalami peningkatan dari tahun ke tahun. Sedangkan disisi lain penduduk negara Indonesia yang mayoritas muslim masih belum menjadi key driver dalam halal industri di Indonesia dan secara global. Indonesia sendiri pada saat ini dengan jumlah penduduk mayoritas muslim adalah sebagai negara yang memiliki peluang besar dan potensi pasar yang menjanjikan untuk produk halal. Dan dapat dilihat pada saat ini negara Indonesia merupakan negara pengimpor pangan halal terbesar keempat dalam Global Islamic Report.

\section{DAFTAR PUSTAKA}

Al Qur'an al Karim

Alma, Buchari dan Donni Juni Priansa.(2009). Mahajemen Bisnis Syari'ah. Bandung. Alfabeta.

Badan Perencanaan Pembagunan Nasional. (2018). Masterplan Ekonomi Syariah Indonesia 2019- 2024. Kementrian Perencanaan Pembangunan Nasional. Jakarta.

Bungin, Burhan. (2012). Metodologi Penelitian Kualitatif: Aktualisasi Metodologis ke Arah Ragam Varian Kontemporer. Rajawali Pers. Jakarta.

Djakfar,Muhammad. (2012). Etika Bisnis Menangkap Spirit Ajaran Langit dan Pesan Moral Ajaran Bumi. 2012. Penebar Plus. Jakarta.

Fahrudin Sukarno.(2020) Etika Produksi Perspektif Ekonomi Islam, Jurnal Ekonomi Islam Al-Infaq Bogor, Vol.1 No.1, September 2020

Housman, Daniel dan Michael McPherson. (1996). Economic Analysis and Moral Philosophy. Cambridge: Cambridge up. 
Haider Naqvi. (1981).Ethics and Economics: an Synthesis Leicester: The Islamic Foundation.

Nawawi, Ismail. (2013). ISU NALAR EKONOMI ISLAM Kompilasi Pemikiran Filsafat dan Teori Menuju Praktik di Tengah Arus Ekonomi Global. Sidoarjo, Dwiputra Pustaka Jaya.

Sri Laksmi Pardanawati. (2015). Perilaku Produsen Islam, Jurnal Ilmiah Ekonomi Islam-vol. 01, no. 01, Maret 2015. ISSN: 2477-6157.

Sukirno, Sadono.(1997). Pengantar Teori Mikroekonomi. Jakarta. PT RajaGrafindo Persada.

Sulaiman, S., Aldeehani, A., Aziz, F.A., dan Mustpha, F. (2018). Integrated Halal Supply Chain System in Food Manufacturing Industry. Journal Of Industrial Engineering Research, 2018. 4(3): 1-5.

Tieman M, Van der Vorst J.G.A.J. dan Ghazali M.C. (2012). Principle in Halal Suppy Chain Management. Journal of Islamic Marketing. Vol. 3 No. 3, pp.217-243

Wibisono,Koento. (1983). Arti Perkembangan Menurut Filsafat Positivisme Auguste Comte. Yogyakarta. Gajah Mada University.

Yeni Rohaeni dan Ahmad Hidayat Sutawidjaya.(2020). Pengembangan Model Konseptual Manajemen Rantai Pasok Halal Studi Kasus Indonesia, J@ti Undip: Jurnal Teknik Industri, Vol.15, No.3

www. knks go.id.

www.salaamgateway.com. The Global Islamic Economy 2020/2021 Report 